\title{
Citations, non-citations and visibility of International Orthopaedics in 2017
}

\author{
Andreas F. Mavrogenis ${ }^{1} \cdot$ Andrew Quaile $^{2} \cdot$ Marko Pećina $^{3} \cdot$ Marius M. Scarlat $^{4}$
}

Published online: 8 October 2018

(C) SICOT aisbl 2018

\section{Introduction}

In 2017, International Orthopaedics, the official journal of Société Internationale de Chirurgie Orthopédique et de Traumatologie (SICOT), received over 2600 submissions to be considered for publication. After peer-review and editorial evaluation, 346 papers were published. Sixty-four papers were included in special issues, one dedicated to Traumatology and one dedicated to the Double Mobility Hip. Overall, the Journal published 289 original research papers, 33 review articles, 12 historical research papers and 12 items related to journal metrics, Editorials, acknowledgements to reviewers, orbituaries, erratae and others.

Although the scientific quality of a paper or of a journal is not uniquely based on citation metrics, the more a paper (or journal) is cited reflects the overall impact of the paper and journal on the scientific community $[1,2]$. However, not all published papers are cited; some are cited early after publication, while others are cited late (usually within 2-5 years) and some never. This editorial aims to identify and categorize the non-cited papers published by International Orthopaedics in 2017, attempting to provide insights into why some papers were not cited.

Marius M. Scarlat

mscarlat@gmail.com

1 First Department of Orthopaedics, School of Medicine, National and Kapodistrian University of Athens, Athens, Greece

2 Hampshire Clinic, Basingstoke, England

3 Department of Orthopaedics, School of Medicine, University of Zagreb, Zagreb, Croatia

4 Clinique St. Michel, Toulon, France

\section{Citations of International Orthopaedics in 2017}

Two hundred and fifty-three papers (73\% of the papers published in 2017) were cited 701 times, with an average citation per paper of 2.75 (range, 1-23 citations per paper), and an hindex of 9 [3]. The self-citations rate was $17.4 \%$, without any correlation between total citations (701) and self-citations (122) [4]. Most of the cited papers were published early in the year 2017, except six papers [5-10] that were published at the second semester of the year and were cited four to six times each.

Ninety-three papers (27\% of the papers published in 2017) did not receive any citations up to the time of writing [11-102]. The article type, origin, reviewing and editorial process of the non-cited papers was similar to that of the cited papers. The non-cited papers covered almost every aspect of orthopaedics, mainly trauma, arthroscopic surgery and sports medicine, adult reconstruction, oncology and spine. Most non-cited papers were uncontrolled retrospective case series, experimental and in vitro studies (77 papers). The origin was European (44 papers), followed by Asian (18 papers) and North-American (14 papers). Seven non-cited papers were Letters to the Editor [11-13, 16, 26, 28, 35], and one was an Obituary [102]. Obviously, these types of papers (nonsourcable but citable items in the impact factor calculation) are not cited more compared to other types of article (source items). They do not contribute more to the impact factor of a journal, and most likely do not add to current literature [103].

A journal's contribution to scientific literature and its impact on the scientific community is reflected by its citations. Specifically, the acknowledgment one article gives to another is a reference, whereas the acknowledgment that the referenced article receives is a citation [104]. Citation counts vary considerably by research area and databases. The Internet has dramatically changed the way of sharing and the speed of flow of medical information. In general, Google Scholar shows a greater number of citations, followed by Scopus ${ }^{\circledR}$ and then 
Web of Science®. Currently, web platforms and professional sites provide specific information on defined fields of science, and social media have allowed for inputs from the general public. These are changing the scene of the publication industry from the concept of impact factor to alternative metrics (altmetrics) that measure the impact of a paper based on social media attention including number of downloads, reads, views, clicks, likes, hits and tweets [105]. Sourced from the Web, altmetrics can measure how often papers and other scholarly outputs like datasets are discussed and used around the world. For example, a paper published in 2017 received 2-3 citations in JCR, but more than 1500 reads and downloads in the same time period [106]. Therefore, it is important to consider altmetrics in the evaluation of scientific papers. From the Editors' point of view, we do feel concerned about the citation of published papers and the visibility of our Journal. The number of citations and the Impact factor of International Orthopaedics are in constant growth over the last forty years. This fact is even more valuable as the number of pages, issues and published articles has also increased during the same timeframe. Cited and non-cited papers are a part of the package. Non-cited papers should not be criticized for inappropriate language or presentation because they have been evaluated by the same Reviewers' panel and accepted by the same Editors. Some of the papers come from countries and institutions with low visibility and may be criticized for methods that lack modernity or data processing. Some papers come from countries that are in state of war or poverty. We do not expect citations for some papers as they reflect the current state of the orthopaedic surgery in those institutions and not the complete 'state of art' of modern orthopaedics. They are honest work and contain true data. We do believe that these papers add substantial knowledge to the current literature, and most likely will be helpful to the readers and will be cited in the future.

\section{Why not cite a paper?}

Scientific writing should be formal and follow standard rules of spelling, grammar and syntax. It is usually the editorial office that handles these issues. If major language errors exist and the paper is poorly written, it is more likely to be rejected; therefore, writing and language errors are not criteria used to cite a paper or not. Considering the countries of origin, USA submissions are more likely to be accepted, ranked more favorably, and probably cited more compared to non-USA submissions [107]. The lower availability of financial resources and subsequently the lower scientific publishing activity in non-USA and non-European countries may explain the lower contribution to scientific literature of these countries and probably the lower citation rate of their submitted papers [108-110].

Considering the articles types, most submitted papers are clinical case series, which although may be directly relevant to patient care and may be useful for a decision making approach, in most cases their topics lack substantial novelty. In this setting, an accumulation of cases in a published paper does not seem likely to lead to an important change or improvement in practice, and therefore the paper to be cited in a subsequent publication. Review articles tend to attract greater numbers of citations because they are easier to read, include more information and discussion on a topic and are usually open access; in comparison, original research papers receive more citations when they are important or when they bring novelty. Additionally, authors' comments and Letters to the Editor on a published paper, erratums, obituaries, and historical notes on a topic without contemporary use are most likely not to be cited at all. Papers considering research areas, adult reconstruction, sports medicine and trauma are the most commonly quoted. Although this explains an increased interest for new knowledge and research in these areas, unfortunately, to date not much new information is available to merit a citation.

The time elapsed since publication should also be considered. One or two years may pass before one paper is cited. Similarly, an article reaches the maximum of citations between three to ten years after publication, with citation rate expected to decline thereafter [111]. Therefore, the papers published in 2017 are expected to receive citations through time. Another possible variable is the time to impact. An extremely specialized paper, basic research or novel material may need more time to launch in its field and become practice; therefore, the original papers will take more time to be cited. Nevertheless, we are aware that the choice of citations is subjective and reflects significant authors' biases. Additionally, we do have a concern about self-citations. Self-citations are more likely for authors submitting their papers in high-impact journals compared to those publishing in lower-impact journals [112]. However, self-citation rates of papers published in International Orthopaedics were found to be very low between the reviewed papers, raising no concerns in regards to potential citation inflation [4].

International Orthopaedics is free of publication fees, and one choice 'open access' journal. After an article has been accepted for publication, the authors receive an email with a link where they can opt for their article to be published 'open access' with a publication fee. Few authors agree for their paper to be published 'open access', most likely due to financial issues or because they think 'open access' is equal to easy publishing, or just because they are not interested. We acknowledge these limitations of 'open access'. Since many readers evaluate primarily the abstract of a paper, the papers published in International Orthopaedics contain a structured abstract written as a synopsis of the article and a mirror of the outline of the paper. In our review and editorial process, we do insist on scientifically correct abstract formatting and writing 
because we believe that a reader should be able to understand a paper by reading its abstract. However, we do concur that citing a paper by just reading its abstract may be flawed by incorrect conclusions and bring consequently a wrong or inaccurate citation.

In a paper, it is possible to use other people's words and ideas, but with mandatory labeling and reference to the source from which these words and ideas are taken so that the readers can recognize whether something is written in original work or just copied from another text. Copying and using other people's ideas or work without providing appropriate credit (citations) is prohibited, and is called plagiarism. Therefore, to avoid plagiarism, appropriate citations of any text that is not authors' own material is necessary.

Many authors take referencing lightly. Citations should be driven by the quality of the cited papers, and not by social factors or strategic considerations. It does make a difference to include up-to-date citations in a published paper. The citation is the information that is necessary for the readers to identify and find used sources; however, citations must be accurate, complete and consistently applied. Failing to cite appropriate work of colleagues is not fair and does not contribute to medical writing. A good argument can be made for a related study instead of failing to cite; especially if there is something fundamentally wrong with it, the authors should include it and discuss it in their paper with an appropriate citation. Including recent references and data points to a quality and up-to-date paper, therefore we encourage the authors to read and cite items issued during the last five years.

\section{Compliance with ethical standards}

Conflict of interest No benefits have been or will be received from a commercial party related directed or indirectly to the subject matter of this article.

Ethical approval This article does not contain any studies with human participants or animals performed by any of the authors.

Informed consent Informed consent was obtained from all individual participants included in the study.

\section{References}

1. Mavrogenis AF, Quaile A, Scarlat MM (2016) Attractive papers and accurate English. Int Orthop 40(4):649-651. https://doi.org/ 10.1007/s00264-016-3172-9

2. Scarlat MM, Hinsenkamp M, Quaile A, Pecina M (2016) International Orthopaedics is $4 \mathrm{O}$ years old! Int Orthop 40(8): 1563-1569

3. InCites Journal Citation Reports (2018) Available at: https:// clarivate.com/products/journal-citation-reports/. Accessed on: September 29, 2018
4. Mavrogenis AF, Megaloikonomos PD, Panagopoulos GN, Mauffrey C, Quaile A, Scarlat MM (2017) Best one hundred papers of international Orthopaedics: a bibliometric analysis. Int Orthop 41(4):689-697. https://doi.org/10.1007/s00264-0163376-Z

5. Chen KH, Tsai SW, Wu PK, Chen CF, Wang HY, Chen WM (2017) Partial component-retained two-stage reconstruction for chronic infection after uncemented total hip arthroplasty: results of sixteen cases after five years of follow-up. Int Orthop 41(12): 2479-2486. https://doi.org/10.1007/s00264-017-3505-3

6. Bliemel C, Buecking B, Oberkircher L, Knobe M, Ruchholtz S, Eschbach D (2017) The impact of pre-existing conditions on functional outcome and mortality in geriatric hip fracture patients. Int Orthop 41(10):1995-2000. https://doi.org/10.1007/s00264-0173591-2

7. Imam MA, Holton J, Ernstbrunner L, Pepke W, Grubhofer F, Narvani A, Snow M (2017) A systematic review of the clinical applications and complications of bone marrow aspirate concentrate in management of bone defects and nonunions. Int Orthop 41(11):2213-2220. https://doi.org/10.1007/s00264-017-3597-9

8. Zhang B, Chang H, Yu K, Bai J, Tian D, Zhang G, Shao X, Zhang Y (2017) Intramedullary nail versus volar locking plate fixation for the treatment of extra-articular or simple intra-articular distal radius fractures: systematic review and meta-analysis. Int Orthop 41(10):2161-2169. https://doi.org/10.1007/s00264-017-3460-Z

9. Cho JW, Kim J, Cho WT, Kim JK, Samal P, Gujjar PH, Kent WT, Oh JK (2017) Approaches and fixation of the posterolateral fracture fragment in tibial plateau fractures: a review with an emphasis on rim plating via modified anterolateral approach. Int Orthop 41(9):1887-1897. https://doi.org/10.1007/s00264-017-3563-6

10. Lou Y, Cai L, Wang C, Tang Q, Pan T, Guo X, Wang J (2017) Comparison of traditional surgery and surgery assisted by three dimensional printing technology in the treatment of tibial plateau fractures. Int Orthop 41(9):1875-1880. https://doi.org/10.1007/ s00264-017-3445-y

11. Liu X, Wu H, Zhang K, Zhang L (2017) Comment on Andrei Diana et al.: the variability of vertebral body volume and pain associated with osteoporotic vertebral fractures: conservative treatment versus percutaneous transpedicular vertebroplasty. Int Orthop 41(12):2637-2638. https://doi.org/10.1007/s00264-0173636-6

12. Yin H (2017) Comment on Kortram et al.: risk factors for infectious complications after open fractures; a systematic review and meta-analysis. Int Orthop 41(12):2633-2634. https://doi.org/10. 1007/s00264-017-3606-z

13. Zhang H, Xiao T (2017) Letter regarding article by Kortram et al.: risk factors for infectious complications after open fractures: a systematic review and meta-analysis. Int Orthop 41(12):26352636. https://doi.org/10.1007/s00264-017-3624-x

14. Zhang X, Shao X, Yu Y, Zhang Y, Zhang G, Tian D (2017) Comparison between percutaneous and open reduction for treating paediatric talar neck fractures. Int Orthop 41(12):25812589. https://doi.org/10.1007/s00264-017-3631-y

15. Bao T, Han F, Xu F, Yang Y, Shu X, Chen K, Qi B, Wei S, Yu A (2017) Papineau technique combined with vacuum-assisted closure for open tibial fractures: clinical outcomes at five years. Int Orthop 41(11):2389-2396. https://doi.org/10.1007/s00264-017$3620-1$

16. Guo HB, He HB (2017) Letter regarding article by li AB et al.: intramedullary and extramedullary fixations for the treatment of unstable femoral intertrochanteric fractures: a meta-analysis of prospective randomized controlled trials. Int Orthop 41(11): 2425-2426. https://doi.org/10.1007/s00264-017-3530-2

17. Liu JM, Deng HL, Zhou Y, Chen XY, Yang D, Duan MS, Huang SH, Liu ZL (2017) Incidence and risk factors for symptomatic spinal epidural haematoma following lumbar spinal surgery. Int 
Orthop 41(11):2297-2302. https://doi.org/10.1007/s00264-0173619-7

18. Cai L, Lou Y, Guo X, Wang J (2017) Surgical treatment of unstable pelvic fractures with concomitant acetabular fractures. Int Orthop 41(9):1803-1811. https://doi.org/10.1007/s00264-0173532-0

19. Fang C, Alabdulrahman H, Pape HC (2017) Complications after percutaneous internal fixator for anterior pelvic ring injuries. Int Orthop 41(9):1785-1790. https://doi.org/10.1007/s00264-017$3415-4$

20. Zhao W, Qu W, Fu C, Jiang H, Liu S, Cheng C (2017) Anterolateral minimally invasive plate osteosynthesis (MIPO) with the radial nerve exploration for extra-articular distal-third diaphyseal fractures of the humerus. Int Orthop 41(9):1757-1762. https://doi. org/10.1007/s00264-017-3514-2

21. Zhang T, Chen W, Sun J, Zhang Q, Zhang Y (2017) Minimally invasive plate osteosynthesis technique for displaced midshaft clavicular fracture using the clavicle reductor. Int Orthop 41(8): 1679-1683. https://doi.org/10.1007/s00264-016-3392-z

22. Liu SY, He YB, Deng SY, Zhu WT, Xu SY, Ni GX (2017) Exercise affects biological characteristics of mesenchymal stromal cells derived from bone marrow and adipose tissue. Int Orthop 41(6):1199-1209. https://doi.org/10.1007/s00264-017-3441-2

23. Min L, Zhou Y, Tang F, Zhang W, Luo Y, Duan H, Tu C (2017) Reconstruction with scapular hemiarthroplasty endoprosthesis after scapulectomy for malignant tumour. Int Orthop 41(5):10571063. https://doi.org/10.1007/s00264-017-3429-y

24. Zhang D, Gao X, Jiang J, Kong F, Shen Y, Ding W, Hao X, Cui H (2017) Safe placement of lateral mass screw in the subaxial cervical spine: a case series. Int Orthop 41(4):781-788. https://doi.org/ 10.1007/s00264-017-3423-4

25. Liu Y, Zheng Y, Shen Z, Wang S, Wei X, Gu X, Zhan H, Kuang Y (2017) Interlocking intramedullary nail fixation with additional bone grafting from trochanter via a femoral hollow trephine in the treatment of femoral shaft fractures: design and clinical application. Int Orthop 41(2):397-402. https://doi.org/10.1007/ s00264-016-3207-2

26. Zhang S, Lan X, Lan J (2017) Comment on Qian et al. entitled "outcomes of radical debridement versus no debridement for the treatment of thoracic and lumbar spinal tuberculosis". Int Orthop 41(2):341-342. https://doi.org/10.1007/s00264-016-3335-8

27. Gong MQ, Huang XW, Wang C, Zha YJ, Li Y, Zhang LD, Jiang XY, Wang MY (2017) Management of chronic neglected lateral condyle elbow non-union in adults: functional results of a cohort study and a proposed treatment algorithm. Int Orthop 41(1):157164. https://doi.org/10.1007/s00264-016-3276-2

28. Zhao Y, Zhu Y, Yan G, Cheng S (2017) Letter regarding article by Hyun Jung Kim et al.: Total ankle arthroplasty versus ankle arthrodesis for the treatment of end-stage ankle arthritis: a metaanalysis of comparative studies. Int Orthop 41(1):111. https:// doi.org/10.1007/s00264-016-3331-z

29. Elnady B, Shawky A, Abdelrahman H, Elmorshidy E, ElMeshtawy M, Said GZ (2017) Posterior only approach for fifth lumbar corpectomy: indications and technical notes. Int Orthop 41(12):2535-2541. https://doi.org/10.1007/s00264-017-3570-7

30. Kenawey M (2017) Surgical considerations with the operative fixation of unstable paediatric pelvic ring injuries. Int Orthop 41(9):1791-1801. https://doi.org/10.1007/s00264-017-3475-5

31. Di Iorio A, Viste A, Fessy MH, Besse JL (2017) The AES total ankle arthroplasty analysis of failures and survivorship at ten years. Int Orthop 41(12):2525-2533. https://doi.org/10.1007/ s00264-017-3605-0

32. Di Laura A, Hothi HS, Henckel J, Cerquiglini A, Liow MHL, Kwon YM, Skinner JA, Hart AJ (2017) Retrieval evidence of impingement at the third articulation in contemporary dual mobility cups for total hip arthroplasty. Int Orthop 41(12):24952501. https://doi.org/10.1007/s00264-017-3523-1

33. Metsemakers WJ, Onsea J, Neutjens E, Steffens E, Schuermans A, McNally M, Nijs S (2017) Prevention of fracture-related infection: a multidisciplinary care package. Int Orthop 41(12):2457-2469. https://doi.org/10.1007/s00264-017-3607-y

34. Yan SG, Woiczinski M, Schmidutz TF, Weber P, Paulus AC, Steinbrück A, Jansson V, Schmidutz F (2017) Can the metaphyseal anchored Metha short stem safely be revised with a standard CLS stem? A biomechanical analysis. Int Orthop 41(12): 2471-2477. https://doi.org/10.1007/s00264-017-3497-z

35. Argemi X (2017) Comment on the article "Staphylococcus lugdunensis: a neglected pathogen of infections involving fracture-fixation devices". Int Orthop 41(11):2423-2424. https:// doi.org/10.1007/s00264-017-3586-z

36. Casabianca L, Kreps S, Helfre S, Housset M, Anract P, Biau DJ (2017) Optimal post-operative radiation after soft-tissue sarcoma resection is achieved in less than two thirds of cases. Int Orthop 41(11):2401-2405. https://doi.org/10.1007/s00264-017-3609-9

37. Gorter J, Ploegmakers JJW, Ten Have BLEF, Schreuder HWB, Jutte PC (2017) The push-through total femoral prosthesis offers a functional alternative to total femoral replacement: a case series. Int Orthop 41(11):2237-2244. https://doi.org/10.1007/s00264017-3467-5

38. Krishnakumar GS, Roffi A, Reale D, Kon E, Filardo G (2017) Bone Morphogenic protein augmentation for long bone healing" response to "clinical need for bone morphogenetic protein. Int Orthop 41(11):2417-2419. https://doi.org/10.1007/s00264-0173595-y

39. Putzer D, Moctezuma JL, Nogler M (2017) Computer aided planning of orthopaedic surgeries: the definition of generic planning steps for bone removal procedures. Int Orthop 41(11):2221-2227. https://doi.org/10.1007/s00264-017-3626-8

40. Reynaud O, Batailler C, Lording T, Lustig S, Servien E, Neyret P (2017) Three dimensionalCT analysis of femoral tunnel position after ACL reconstruction. A prospective study of one hundred and thirty five cases. Int Orthop 41(11):2313-2319. https://doi.org/10.1007/s00264-0173596-x

41. Vinagre G, Alfonso M, Cruz-Morande S, Hernández M, Villas C (2017) Efficacy of pedobarographic analysis to evaluate proximal medial gastrocnemius recession in patients with gastrocnemius tightness and metatarsalgia. Int Orthop 41(11):2281-2287. https://doi.org/10.1007/s00264-017-3621-0

42. Baier C, Wolfsteiner J, Otto F, Zeman F, Renkawitz T, Springorum HR, Maderbacher G, Grifka J (2017) Clinical, radiological and survivorship results after ten years comparing navigated and conventional total knee arthroplasty: a matched-pair analysis. Int Orthop 41(10):2037-2044. https://doi.org/10.1007/s00264-017-3509-z

43. Bouloussa H, Alzakri A, Ghailane S, Vergari C, Mazas S, Vital JM, Coudert P, Gille O (2017) Is it safe to perform lumbar spine surgery on patients over eighty five? Int Orthop 41(10):20912096. https://doi.org/10.1007/s00264-017-3555-6

44. Floerkemeier T, Budde S, Wirries N, von Lewinski G, Windhagen H, Ezechieli M (2017) The outcome of the partial resurfacing arthroplasty of the hip shows high numbers of failures and conversion to total arthroplasty. Int Orthop 41(10):2001-2008. https:// doi.org/10.1007/s00264-017-3594-z

45. Frigg A, Germann U, Huber M, Horisberger M (2017) Survival of the Scandinavian total ankle replacement (STAR): results of ten to nineteen years follow-up. Int Orthop 41(10):2075-2082. https:// doi.org/10.1007/s00264-017-3583-2

46. Hernigou P, Gravina N, Potage D, Dubory A (2017) History of club-foot treatment; part II: tenotomy in the nineteenth century. Int 
Orthop 41(10):2205-2212. https://doi.org/10.1007/s00264-0173578-z

47. Magrill ACL, Nakano N, Khanduja V (2017) Historical review of arthroscopic surgery of the hip. Int Orthop 41(10):1983-1994. https://doi.org/10.1007/s00264-017-3454-x

48. Sailhan F, Jacob L, Hamadouche M (2017) Differences in limb alignment and femoral mechanical-anatomical angles using two dimension versus three dimension radiographic imaging. Int Orthop 41(10):2009-2016. https://doi.org/10.1007/s00264-0173428-z

49. Sariali E, Knaffo Y (2017) Three-dimensional analysis of the proximal anterior femoral flare and torsion. Anatomic bases for metaphyseally fixed short stems design. Int Orthop 41(10):20172023. https://doi.org/10.1007/s00264-017-3435-0

50. Valenti P, Maqdes A, Werthel JD (2017) Clinical and radiological outcomes after reverse shoulder arthroplasty in patients with failed deltoid or latissimus dorsi transfers. A review of ten cases. Int Orthop 41(10):2143-2148. https://doi.org/10.1007/s00264-0173520-4

51. Bartoníček J, Tuček M, Klika D (2017) Inferior glenoid fossa fractures: patho-anatomy and results of operative treatment. Int Orthop 41(9):1741-1748. https://doi.org/10.1007/s00264-0173511-5

52. Frigg A, Maquieira G, Horisberger M (2017) Painful stress reaction in the posterior subtalar joint after resection of os trigonum or posterior talar process. Int Orthop 41(8):1585-1592. https://doi. org/10.1007/s00264-017-3489-z

53. Neumann H, Stadler A, Heuer H, Auerswald M, Gille J, Schulz AP, Kienast B (2017) Complications during removal of conventional versus locked compression plates: is there a difference? Int Orthop 41(8):1513-1519. https://doi.org/10.1007/s00264-016$3352-7$

54. Andrin J, Pottecher P, Viard B, Baulot E, Trouilloud P, Martz P (2017) Linear relationship between lateralization of the bicipital groove and humeral retroversion and its link with the biepicondylar humeral line. Anatomical study of seventy cadaveric humerus scans. Int Orthop 41(7):1431-1434. https://doi.org/10. 1007/s00264-017-3495-1

55. Dubory A, Mascard E, Dahan M, Anract P, Court C, Boisgard S, Viard B, Missenard G, SOFCOT (The French Society of Orthopaedic and Trauma Surgery) (2017) Long-term functional and radiological outcomes of allograft hip prosthesis composite. A fourteen-year follow-up study. Int Orthop 41(7):1337-1345. https://doi.org/10.1007/s00264-016-3351-8

56. Laumonerie P, Ancelin D, Reina N, Tibbo ME, Kerezoudis P, Delclaux S, Bonnevialle N, Mansat P (2017) Causes for early and late surgical re-intervention after radial head arthroplasty. Int Orthop 41(7):1435-1443. https://doi.org/10.1007/s00264-0173496-0

57. Vielgut I, Dauwe J, Leithner A, Holzer LA (2017) The fifty highest cited papers in anterior cruciate ligament injury. Int Orthop 41(7):1405-1412. https://doi.org/10.1007/s00264-0173513-3

58. Ziegler P, Friederichs J, Hungerer S (2017) Fusion of the subtalar joint for post-traumatic arthrosis: a study of functional outcomes and non-unions. Int Orthop 41(7):1387-1393. https://doi.org/10. 1007/s00264-017-3493-3

59. Gurzu S, Turdean SG, Pop ST, Zazgyva A, Roman CO, Opris M, Jung I (2017) Different synovial vasculogenic profiles of primary, rapidly destructive and osteonecrosis-induced hip osteoarthritis. An immunohistochemistry study. Int Orthop 41(6):1107-1112. https://doi.org/10.1007/s00264-016-3302-4

60. Khatkar H, Hothi H, de Villiers D, Lausmann C, Kendoff D, Gehrke T, Skinner J, Hart A (2017) Retrieval analysis of ceramic-coated metal-on-polyethylene total hip replacements. Int
Orthop 41(6):1101-1105. https://doi.org/10.1007/s00264-0163314-0

61. Sabine K, Sascha A, Peter B, Clemens M, Michel C, Hans-Joerg T (2017) Comparative study of outcomes after ankle arthrodesis shows higher complication rates in cases operated upon by general orthopaedic surgeons. Int Orthop 41(6):1163-1168. https://doi. org/10.1007/s00264-017-3459-5

62. Georgiannos D, Boutsiadis A, Agathangelidis F, Papastergiou S, Karataglis D, Bisbinas I (2017) Arthroscopically-assisted mini open partial synovectomy for the treatment of localized pigmented villonodular synovitis of the knee. A retrospective comparative study with long-term follow up. Int Orthop 41(5):925-930. https://doi.org/10.1007/s00264-016-3348-3

63. Miquel J, Santana F, Torrens C (2017) A vast majority of preliminary reports published in the shoulder literature are not followed by long-time follow-up studies - a literature review. Int Orthop 41(5):869-875. https://doi.org/10.1007/s00264-016-3228-x

64. Moraiti C, Klouche S, Werthel JD, Bauer T, Hardy P (2017) Description and reproducibility assessment of a new computerised tomography scan index to measure the glenoid orientation in relation to the anterior glenoid surface. Int Orthop 41(5):1017-1022. https://doi.org/10.1007/s00264-016-3290-4

65. Madanat R, Mäkinen TJ, Ryan D, Huri G, Paschos N, Vide J, FORTE writing committee (2017) The current state of orthopaedic residency in 18 European countries. Int Orthop 41(4):681-687. https://doi.org/10.1007/s00264-017-3427-0

66. Philippot R, Neri T, Boyer B, Viard B, Farizon F (2017) Bousquet dual mobility socket for patient under fifty years old. More than twenty year follow-up of one hundred and thirty one hips. Int Orthop 41(3):589-594. https://doi.org/10.1007/s00264-0163385-y

67. Zoccali C, Attala D, Scotto di Uccio A, Rossi B, Scotto G, Biagini $R$ (2017) The dual mobility cup in muscular skeletal oncology: rationale and indications. Int Orthop 41(3):447-453. https://doi. org/10.1007/s00264-017-3407-4

68. Pollon T, Reina N, Delclaux S, Bonnevialle P, Mansat P, Bonnevialle N (2017) Persistent non-union of the humeral shaft treated by plating and autologous bone grafting. Int Orthop 41(2): 367-373. https://doi.org/10.1007/s00264-016-3267-3

69. Reikerås $\mathrm{O}$ (2017) Femoral revision surgery using a fully hydroxyapatite-coated stem: a cohort study of twenty two to twenty seven years. Int Orthop 41(2):271-275. https://doi.org/10. 1007/s00264-016-3204-5

70. Woerner M, Weber M, Sendtner E, Springorum R, Worlicek M, Craiovan B, Grifka J, Renkawitz T (2017) Soft tissue restricts impingement-free mobility in total hip arthroplasty. Int Orthop 41(2):277-282. https://doi.org/10.1007/s00264-016-3216-1

71. Lubiatowski P, Długosz J, Ślęzak M, Ogrodowicz P, Stefaniak J, Walecka J, Romanowski L (2017) Effect of arthroscopic techniques on joint volume in shoulder instability: Bankart repair versus capsular shift. Int Orthop 41(1):149-155. https://doi.org/10. 1007/s00264-016-3275-3

72. Prejbeanu R, Poenaru DV, Balanescu AD, Mioc ML (2017) Long term results after arthroscopic resection of medial plicae of the knee-a prospective study. Int Orthop 41(1):121-125. https://doi. org/10.1007/s00264-016-3313-1

73. Malhotra R, Jain V, Kumar V, Gautam D (2017) Evaluation of running knotless barbed suture for capsular closure in primary total knee arthroplasty for osteoarthritis-a prospective randomized study. Int Orthop 41(10):2061-2066. https://doi.org/10.1007/ s00264-017-3529-8

74. Agarwal A, Kumar D, Agrawal N, Gupta N (2017) Ankle valgus following non-vascularized fibular grafts in children-an outcome evaluation minimum two years after fibular harvest. Int Orthop 41(5):949-955. https://doi.org/10.1007/s00264-017-3403-8 
75. Kamal A, Kanakeshwar RB, Shyam A, Jayaramaraju D, Agraharam D, Perumal R, Rajasekaran S (2017) Variation in practice preferences in management of open injuries of extremities-an international survey by SICOT research academy. Int Orthop 41(1):3-11. https://doi.org/10.1007/s00264-016-3311-3

76. Kobayashi H, Ito N, Akiyama T, Okuma T, Kinoshita Y, Ikegami M, Shinoda Y, Fukumoto S, Tanaka S, Kawano H (2017) Prevalence and clinical outcomes of hip fractures and subchondral insufficiency fractures of the femoral head in patients with tumour-induced osteomalacia. Int Orthop 41(12):2597-2603. https://doi.org/10.1007/s00264-017-3610-3

77. Sasaki G, Watanabe Y, Takaki M, Yasui Y, Miyamoto W, Kawano H, Matsushita T (2017) Chipping and lengthening over nailing technique for femoral shaft nonunion with shortening. Int Orthop 41(9):1859-1864. https://doi.org/10.1007/s00264-0173535-x

78. Arakura M, Lee SY, Takahara S, Okumachi E, Iwakura T, Fukui T, Nishida K, Kurosaka M, Kuroda R, Niikura T (2017) Altered expression of SDF-1 and CXCR4 during fracture healing in diabetes mellitus. Int Orthop 41(6):1211-1217. https://doi.org/10. 1007/s00264-017-3472-8

79. Matsushita T, Oka S, Araki D, Nishida K, Tanaka T, Kanzaki N, Nishida K, Kuroda R (2017) Patient-based outcomes after medial patellofemoral ligament reconstruction. Int Orthop 41(6):11471153. https://doi.org/10.1007/s00264-017-3433-2

80. Sugita T, Aizawa T, Miyatake N, Sasaki A, Kamimura M, Takahashi A (2017) Preliminary results of managing large medial tibial defects in primary total knee arthroplasty: autogenous morcellised bone graft. Int Orthop 41(5):931-937. https://doi. org/10.1007/s00264-016-3339-4

81. Hoshi M, Oebisu N, Ieguchi M, Ban Y, Takami M, Nakamura H (2017) Clinical features of soft tissue sarcoma presenting intratumour haematoma: case series and review of the literature. Int Orthop 41(1):203-209. https://doi.org/10.1007/s00264-016-3322-0

82. Chamseddine AH, Abdallah A, Zein H, Taha A (2017) Transfracture medial transposition of the radial nerve associated with plate fixation of the humerus. Int Orthop 41(7):1463-1470. https://doi.org/10.1007/s00264-016-3397-7

83. Babikir EME, Al-Maqdassy ED, Hasan K, Abdul Hameed S, Alhammoud A, Al-Dosari MMA (2017) Efficiency of fragment specific fixation plates in the treatment of comminuted distal radial fractures. Int Orthop 41(9):1763-1769. https://doi.org/10.1007/ s00264-017-3516-0

84. Alhammoud A, Arbash MA, Miras F, Said MN, Ahmed G, Al Dosari MA (2017) Clinical series of three hundred and twenty two cases of Achilles tendon section with laceration. Int Orthop 41(2): 309-313. https://doi.org/10.1007/s00264-016-3318-9

85. Lipina M, Makarov M, Makarov S, Novikov A (2017) The degree of cartilage degradation assessed by serum biomarker levels changes after arthroscopic knee synovectomy in rheumatoid arthritis patients. Int Orthop 41(11):2259-2264. https://doi.org/10. 1007/s00264-017-3634-8

86. Yang LM (2017) Treatment of medial compartment knee osteoarthritis by arthroscopic ' $L$ ' medial release procedure. Int Orthop 41(10):2025-2035. https://doi.org/10.1007/s00264-017-3508-0

87. Circi E, Beyzadeoglu T (2017) Results of arthroscopic treatment in unresolved Osgood-Schlatter disease in athletes. Int Orthop 41(2):351-356. https://doi.org/10.1007/s00264-016-3374-1

88. Lopes OV Jr, Tragnago G, Gatelli C, Costa RN, de Freitas Spinelli L, Saggin PRF, Kuhn A (2017) Assessment of the alpha angle and mobility of the hip in patients with noncontact anterior cruciate ligament injury. Int Orthop 41(8):1601-1605. https://doi.org/10. 1007/s00264-017-3482-6

89. Savin DD, Piponov H, Watson JN, Youderian AR, Amirouche F, Solitro GF, Hutchinson MR, Goldberg BA (2017) Biomechanical evaluation of distal biceps tendon repair using tension slide technique and knotless fixation technique. Int Orthop 41(12): 2565-2572. https://doi.org/10.1007/s00264-017-3559-2

90. Statz JM, Chalmers BP, Ledford CK, Sanchez-Sotelo J, Sperling JW, Morrey ME (2017) Outcomes of shoulder arthroplasty in haematopoietic stem cell transplant patients. Int Orthop 41(12): 2555-2564. https://doi.org/10.1007/s00264-017-3553-8

91. Araoye I, De Cesar Netto C, Cone B, Hudson P, Sahranavard B, Shah A (2017) Results of lateral ankle ligament repair surgery in one hundred and nineteen patients: do surgical method and arthroscopy timing matter? Int Orthop 41(11):2289-2295. https:// doi.org/10.1007/s00264-017-3617-9

92. Harvey NR, Wolf BJ, Bolin ED, Wilson SH (2017) Comparison of analgaesia with lumbar epidurals and lumbar plexus nerve blocks in patients receiving multimodal analgaesics following primary total hip arthroplasty: a retrospective analysis. Int Orthop 41(11): 2229-2235. https://doi.org/10.1007/s00264-017-3465-7

93. Stautberg EF 3rd, Jupiter DC, Amin A, Qadeer AA, Ilahi OA (2017) Stability of two versus three peripheral pegs of the glenoid component in modern total shoulder arthroplasty. Int Orthop 41(11):2345-2351. https://doi.org/10.1007/s00264-017-3599-7

94. Pettine KA, Suzuki RK, Sand TT, Murphy MB (2017) Autologous bone marrow concentrate intradiscal injection for the treatment of degenerative disc disease with three-year follow-up. Int Orthop 41(10):2097-2103. https://doi.org/10.1007/ s00264-017-3560-9

95. Schoch B, Werthel JD, Sanchez-Sotelo J, Sperling JW, Cofield RH, Morrey M (2017) Shoulder arthroplasty in patients with osteo-chondrodysplasias. Int Orthop 41(10):2129-2134. https:// doi.org/10.1007/s00264-017-3588-x

96. Shaw JC, MLC R Jr, Gary JL (2017) Intra-operative multi-dimensional fluoroscopy of guidepin placement prior to iliosacral screw fixation for posterior pelvic ring injuries and sacroiliac dislocation: an early case series. Int Orthop 41(10):2171-2177. https://doi.org/ 10.1007/s00264-017-3447-9

97. Alrabai HM, Gesheff MG, Conway JD (2017) Use of internal lengthening nails in post-traumatic sequelae. Int Orthop 41(9): 1915-1923. https://doi.org/10.1007/s00264-017-3466-6

98. Dunn RH, Jackson T, Burlew CC, Pieracci FM, Fox C, Cohen M, Campion EM, Lawless R, Mauffrey C (2017) Fat emboli syndrome and the orthopaedic trauma surgeon: lessons learned and clinical recommendations. Int Orthop 41(9):1729-1734. https:// doi.org/10.1007/s00264-017-3507-1

99. Jensen G, Millett PJ, Tahal DS, Al Ibadi M, Lill H, Katthagen JC (2017) Concomitant glenohumeral pathologies associated with acute and chronic grade III and grade V acromioclavicular joint injuries. Int Orthop 41(8):1633-1640. https://doi.org/10.1007/ s00264-017-3469-3

100. Zhang J, Eisenhauer P, Kaya O, Vaccaro AR, Diallo C, Fertala A, Freeman TA (2017) P15 peptide stimulates chondrogenic commitment and endochondral ossification. Int Orthop 41(7):1413-1422. https://doi.org/10.1007/s00264-017-3464-8

101. Lazennec JY, Chometon Q, Folinais D, Robbins CB, Pour AE (2017) Are advanced three-dimensional imaging studies always needed to measure the coronal knee alignment of the lower extremity? Int Orthop 41(5):917-924. https://doi.org/10.1007/ s00264-016-3340-y

102. Oxland TR, Grant B (2017) Obituary - Dr. George W. Bagby. Int Orthop 41(4):857-858. https://doi.org/10.1007/s00264-0173418-1

103. Mavrogenis AF, Panagopoulos GN, Megaloikonomos PD, Panagopoulos VN, Mauffrey C, Quaile A, Scarlat MM (2017) Scientific misconduct (fraud) in medical writing. Orthopedics 41(2):e176-e183. https://doi.org/10.3928/01477447-20180123-06

104. Ollerton JE, Sugrue M (2005) Citation classics in trauma. J Trauma 58(2):364-369 
105. Scarlat MM, Mavrogenis AF, Pećina M, Niculescu M (2015) Impact and alternative metrics for medical publishing: our experience with international Orthopaedics. Int Orthop 39(8):14591464. https://doi.org/10.1007/s00264-015-2766-y

106. Grgurevic L, Pecina M, Vukicevic S (2017) Marshall R. Urist and the discovery of bone morphogenetic proteins. Int Orthop 41(5): 1065-1069. https://doi.org/10.1007/s00264-017-3402-9

107. Link AM (1998) US and non-US submissions: an analysis of reviewer bias. JAMA 280(3):246-247

108. Rahman M, Fukui T (2003) Biomedical research productivity: factors across the countries. Int J Technol Assess Health Care 19(1):249-252
109. Uthman OA, Uthman MB (2007) Geography of Africa biomedical publications: an analysis of 1996-2005 PubMed papers. Int J Health Geogr 6:46. https://doi.org/10.1186/1476-072X-6-46

110. Perez-Iratxeta C, Andrade MA (2002) Worldwide scientific publishing activity. Science 297(5581):519

111. Baltussen A, Kindler CH (2004) Citation classics in critical care medicine. Intensive Care Med 30(5):902-910. https://doi.org/10. 1007/s00134-004-2195-7

112. Tamaki T, Tsuji H, Si I, Kobayashi H (1981) The prevention of iatrogenic spinal cord injury utilizing the evoked spinal cord potential. Int Orthop 4(4):313-317. https://doi.org/10.1007/ bf00266075 